\title{
HIBERNOMA (GRANULAR CELL LIPOMA)
}

\author{
BY \\ R. C. JENNINGS AND G. BEHR \\ From Crumpsall Hospital, Manchester, and the Central Pathological Laboratory, Burnley
}

(RECEIVED FOR PUBLICATION MAY 2, 1955)

Hibernomas are peculiar and apparently rare benign fatty tumours believed to originate from human brown fatty tissue homologous to the hibernating glandular fatty tissues found in animals. Brines and Johnson (1949) were able to find only nine apparently authentic cases in the literature to which they added one of their own. Six more have since been recorded, all from American sources. We wish to report two further cases.

\section{Case Reports}

Case 1.-A woman aged 47 was admitted to hospital for investigation of a lump in the right buttock. She was not able to say with certainty how long this had been present, but thought that the right buttock had always been larger than the left. She had attended for treatment because of a dull aching pain in her leg which had been present for about a year. There was no relevant previous medical or family history.

On examination she was found to have a soft, mobile subcutaneous swelling some $10 \mathrm{~cm}$. in diameter in the upper and outer quadrant of the right buttock,

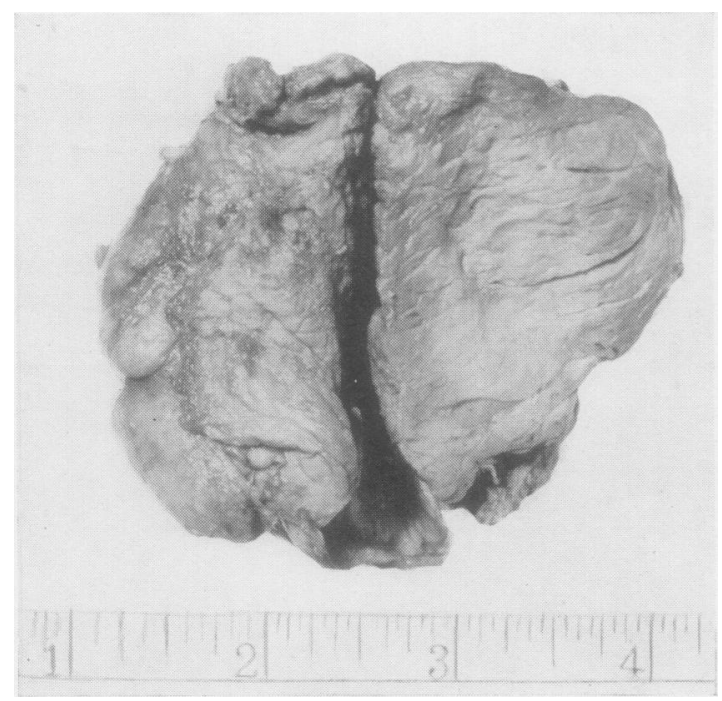

Fig. 1.-Hibernoma in Case 1.

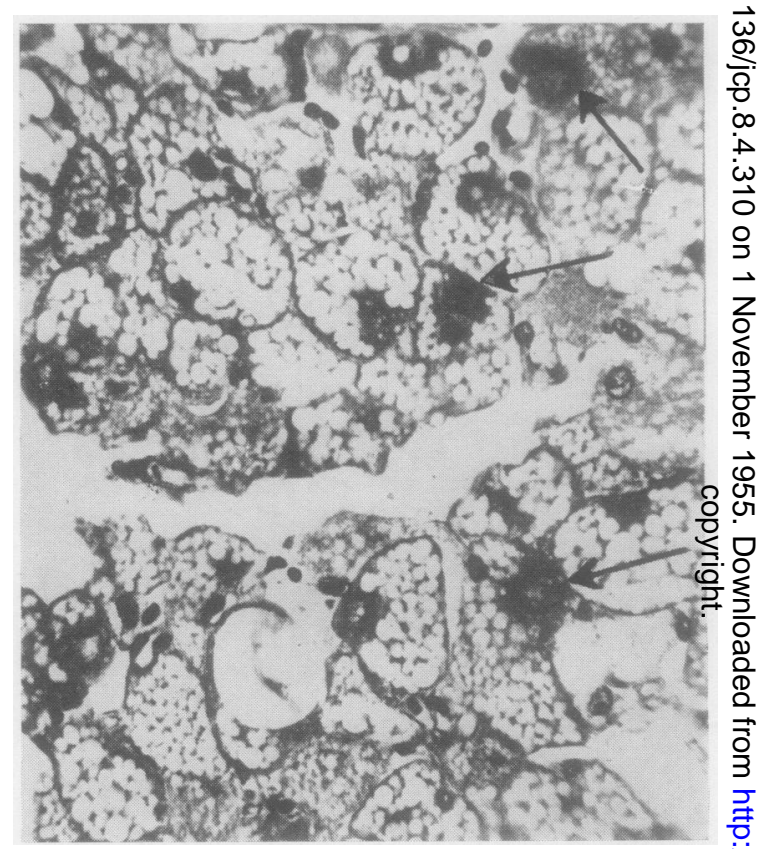

FIG. 2.-Histological section of hibernoma (Case 1) showing typical tumour cells and intracytoplasmic bodies (arrows). (Haematoxylin and eosin, $\times 320$.)

which was considered clinically to be a lipoma. There were no other abnormal clinical findings.

At operation a fairly well circumscribed tumour $\frac{2}{3}$ was present in the subcutaneous soft tissues of the 0 buttock. A complete resection was performed, although some difficulty was experienced because of $\frac{7}{2}$ the intimate connexion of part of the tumour with the tendon of the gluteus maximus.

Convalescence was uneventful, and there has been no sign of recurrence for three months following $N$ operation.

The tumour was rounded, measuring 9 by 7 by $5 \mathrm{~cm}$. $\sigma$ and weighing $165 \mathrm{~g}$. (Fig. 1). It was encapsulated, firm, and presented a uniform lobulated tan-brown appearance on section. Histologically fibrous tissue $\mathbb{\mathscr { D }}$ septa traversed the tumour, dividing it into variously ${ }^{+}$ sized lobules. These were composed of closely packed 7 large $(20-100 \mu)$ round, oval, or polygonal cells showing well-defined cell boundaries. The nuclei were 
central or eccentric but not peripheral, and showed a finely distributed chromatin network. One to three prominent nucleoli were present. The cytoplasm was of a granular, eosinophilic nature with few or many rounded loculi. These granules and vacuoles stained positively with Sudan IV.

In haematoxylin-and-eosin stained sections, round or oval pink-staining intracytoplasmic bodies were found (Fig. 2). These stained a lighter pink than the ordinary granules and were quite distinct from them. They stained positively with Sudan black and the periodic-acid-Schiff stain, and were not acid-fast. They did not stain with Sudan IV. They were considered to be of a phospholipid nature. Stains for free iron were negative.

Case 2.-A miner aged 32 was admitted to hospital complaining of a lump on the left side of the back. This had been noticed for the first time by his wife eight weeks previously and was slowly getting larger.

On examination there was a smooth, soft, mobile subcutaneous swelling to the left of the scapula measuring 5 by $7 \mathrm{~cm}$. One small axillary gland was palpable. The clinical diagnosis was "lipoma."

At operation a well circumscribed tumour was removed completely from the deep surface of the left trapezius. It was uniformly lobulated and of tanbrown colour on section. The histological appearances and staining reactions were identical to those of the first case, except that the pink-staining intracytoplasmic bodies were not present (Fig. 3).

\section{Discussion}

Merkel (1906) described a case of a pseudolipoma in the breast of a woman of 26 , which is probably the first report of a hibernoma. He was impressed by its unusual histological appearance and likened it to a fatty adenoma of sebaceous gland. Gery, in a discussion on a case reported by Bonnel (1914), introduced the term hibernoma because of its histological similarity to the hibernating gland in animals. Hibernal masses of lobular fatty tissue formed of so-called brown fat have been described in a wide variety of hibernating animals and non-hibernating rodents (Auerbach, 1902 ; Rasmussen, 1923). Interscapular, mediastinal, cervical, lumbar, inguinal, and gluteal masses have been recorded. In man the interscapular gland is a paired, lobulated irregular fatty organ situated on the shoulder and extending into the neck (Bonnot, 1908). It is limited externally by the deep fascia and internally by the prevertebral fascia. It is believed to represent the human homologue of hibernating fatty tissue in animals (Hatai, 1902; Bonnot, 1908) although Rasmussen was not convinced on this point. The features common to these fatty collections in normal animals and man and the hibernoma are the

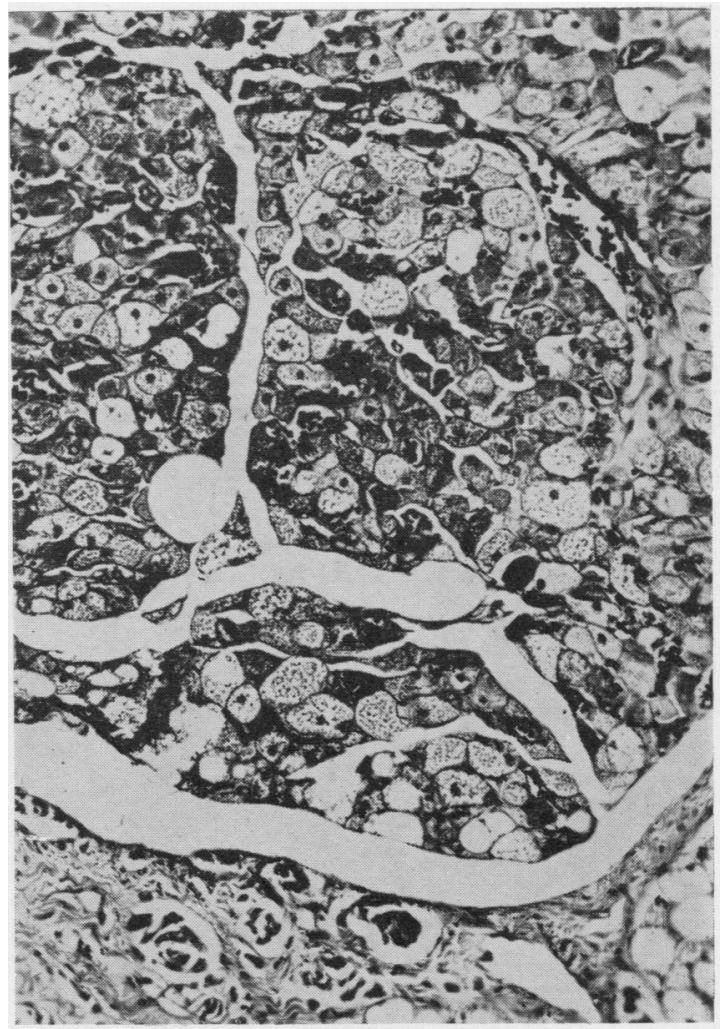

FIG. 3.-Histological section of hibernoma (Case 2) showing interlobular connective tissue stroma and typical granular and multilocular fat cells. (Haematoxylin and eosin, $x$ 140.)

brown colour, lobular structure, and the multilocular appearance of the fat cells.

Brines and Johnson (1949) in their review of the literature on hibernoma were able to find only nine probable cases previously described and seven further doubtful ones. They added one case of their own, a girl aged 18 with a typical hibernoma in the axillary region. Since that time, six cases, all from American sources, have been reported. Two of these were intrathoracic (Kittle, Boley, and Schafer, 1950; Gross and Wood, 1953), one posterior cervical (Simon, 1950), one axillary (Gross and Wood, 1953), one popliteal (Sieber and Heller, 1952), and one in the subcutaneous tissue of the back (Sutherland, Callahan, and Campbell, 1952).

Macroscopically, these tumours are encapsulated and firm. On section they are of an unusual tanbrown colour, which has been likened to the appearance of boiled muscle (Brines and Johnson, 1949). The histological appearances are unique and quite unlike ordinary lipomas or liposarcomas. Connective tissue septa traverse 
the tumour, dividing it into well-marked lobules. These are composed of closely packed large cells (20-100 $\mu$ in diameter), round, oval, or polygonal in shape, possessing well-defined cell boundaries. The nuclei are usually centrally situated, showing a loose chromatin network and one to three prominent nucleoli. Mitoses were not seen in either of our cases. The cytoplasm is granular and eosinophilic with multilocular fat spaces. All gradations are seen between cells with much granular cytoplasm and few fat loculi and those with many fat globules and few, if any, granules. In our Case 1, in addition to these cytoplasmic granules, round or oval eosinophilic intracytoplasma bodies up to $15 \mu$ in diameter were present. These stained positively with Sudan black and periodic-acid-Schiff stain, and were considered to be of a phospholipid nature. We have not seen any record of such a finding in previously reported cases.

Other authors (Brines and Johnson, 1949; Simon, 1950) have observed in these tumours normal adult fat cells with peripherally placed signet ring nuclei, but we have been unable to confirm these findings. Unilocular round spaces were present amongst otherwise typical multilocular fat cells, but they did not show eccentrically placed nuclei and did not stain positively with fat stains. They appeared to be spaces resulting from the degeneration of granular fat cells, with absorption of the previously contained fat. There has been much controversy concerning the histogenesis of yellow fat, and its origin still remains uncertain. Flemming (1879) considered that it developed from ordinary connective tissue cells, whereas Toldt (1888) advanced the conception of specific mesenchymal precursors.

Stout (1944) has shown from studies in vitro that the lipoblast, a special form of connective tissue cell distinct from the fibroblast, is the precursor of adult fat cells and derived, like it, from primitive mesenchymal cells. Whether the lipoblast or some other specialized cell is the precursor of multilocular brown fat cells is not known. Transmutation between these cells and unilocular fat cells would appear from the evidence available to be unlikely to occur. Hammar (1895) was unable to produce unilocular fat cells from the multilocular type in the rat by excessive feeding, and Rasmussen found no intermediate forms, although both types of cell did occur together. However, Metzner (1890) and Cramer (1920) suggested that the granules are transformed into vacuoles which eventually coalesce and form the single large fat globule of the normal adult fat cell.

Hibernomas appear to be specific oncological entities, probably arising from granular, multi- locular fat cells or their precursors. It is interest.-. ing that no true mixed forms showing lipomatous and hibernomatous features have been reported. $\Rightarrow$ Hibernomas must be distinguished from atypical lipomas composed of incompletely differentiated을 fat cells and from granular myoblastomas which $\frac{\bar{\sigma}}{\bar{s}}$ may give a very similar picture in haematoxylin- $\frac{\sqrt{\sigma}}{\bar{\sigma}}$ eosin preparations but will be recognized by theo use of fat stains.

We have found no definite instance of a malig- $\overrightarrow{0}$ nant form of this tumour. However, Lever (1954) depicts a photomicrograph of a malignant hiber- $\vec{\omega}$ noma although there is no detailed reference in $\frac{\text { ? }}{8}$
the text to this case.

Chemical analyses of hibernomas have beenoo performed by Brines and Johnson (1949), Kittle $\stackrel{\vec{\omega}}{\vec{\omega}}$ et al. (1950), and Gross and Wood (1953). The $\frac{\vec{O}}{\circ}$ results of these workers show that these tumourso contain a similar total fat content to ordinary lipomas, although possessing in some instances az higher unsaponifiable fraction.

Although the term hibernoma has been in use $\frac{\mathbb{\Phi}}{3}$ for some 40 years, it is suggested that the desig-D nation "granular cell lipoma" would be more" appropriate until their histogenesis is finallyc $\overrightarrow{0}$ established.

\section{Summary}

Two further hibernomas are described.

The literature is briefly reviewed and the rela tionship of these tumours to hibernating fatty® tissue is discussed. It is suggested that the term $\overrightarrow{\vec{F}}$ "granular cell lipoma" would be more appropriate until their histogenesis is more definitely estab-J lished.

We wish to thank the late Mr. F. H. Scotson and Mr. R. O. Davidson for permission to publish detailso of their cases, and Dr. J. Davson for his helpfuB criticism and advice.

Miss J. L. Perry provided the photomicrographs.

$$
\text { REFERENCES }
$$

Auerbach, M. (1902). Arch. mikr. Anat., 60, 291.

Bonnel, F. (1914). Bull. Soc. anat., Paris (1914-19), 89, 110.

Bonnot, E. (1908). J. Anat., Lond., 43, 43.

Brines, O. A., and Johnson, M. H. (1949). Amer. J. Path., 25, 467.

Cramer, W. (1920). Brit. J. exp. Path., 1, 184.

Flemming, W. (1879). Arch. Anat. Physiol., Lpz. (Anat. abt.), p. 4010

Gross, S., and Wood, C. (1953). Cancer, e, 159.

Hammar, J. A. (1895). Arch. mikr. Anat., 45, 512.

Hatai, S. (1902). Anat. Anz., 21, 369.

Kittle C. F. Boley, J. O and Schafer, P. W. (1950) I. thorac W

Surg., 19, 830. Lever, W.F. (1954). Histopathology of the Skin, 2nd ed. Lippincot t< Philadelphia.

Merkel, H. (1906). Beitr. path. Anat., 39, 152.

Metzner, R. (1890). Arch. Anat. Physiol., Lpz. (Anat. abt.), p. 82. Rasmussen, A. T. (1923). J. Morph., 38, 147.

Sieber, W. K., and Heller, E. L. (1952). Amer. J. clin. Path., 22, $977^{\circ}$

Simon, H. E. (1950). Amer. J. Surg., 80, 127.

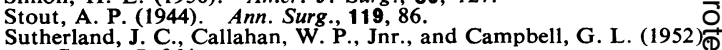
Sutherland, J. C., Callahan, W. P., Jnr., and Campbell, G. L. (1952)
Cancer, 5, 364.
Toldt, C. (1888). Lehrbuch der Gewebelehre, 3rd ed. Enke $\frac{\text { (D) }}{\text { Stuttgart. }}$ 